\title{
Sykepleiefaglig
}

\section{veiledning kan gi bedre helse og økt trivsel}

Sykepleiefaglig veiledning kan gi kolleger en følelse av fellesskap og bidra til et godt arbeidsmiljø. Det kan også gi arbeidstakerne styrke til å tåle utfordringer.

\section{Forfattere}

Turid Neverdal Almvik

Kreftssykepleier, forskningssykepleier og sykepleiefaglig veileder

Avdeling for blodsykdommer, St. Olavs hospital

Gry Bruland Vråle

Sykepleiefaglig veileder, førstelektor og professor emerita

VID vitenskapelige høyskole - Campus Diakonhjemmet, Oslo

Veiledning Stress

Sykepleien 2019 107(75095)(e-75095)

DOI: https://doi.org/10.4220/Sykepleiens.2019.75095

\section{Hovedbudskap}

For å kunne gjøre en god jobb som sykepleier i hele yrkesperioden er det nødvendig med et godt arbeidsmiljø og en god arbeidshelse. Arbeidshelse kan beskrives som en persons motstandskraft til å tåle negativt stress og store utfordringer. Sykepleiefaglig veiledning kan være et bidrag i utviklingen av både godt arbeidsmiljø og motstandskraft ved at kolleger sammen reflekterer over utfordrende hendelser fra praksis og finner nye og bedre handlingsalternativer for liknende utfordringer. 
For å kunne gjøre en god jobb som sykepleier er det nødvendig med et godt arbeidsmiljø og en god arbeidshelse. Veiledningsfellesskap kan styrke arbeidsmiljøet og føre til bedre trivsel. Fellesskapet kan bidra til en samlet kompetanse og kvalitet som gjør oss stolte over profesjonsutøvelsen.

\section{Hva er arbeidshelse?}

«There is a cost to caring. Professionals who listen to clients' stories of fear, pain, and suffering may feel similar fear, pain, and suffering because they care. Sometimes we feel we are losing our own sense of self to the clients we serve.» Charles R. Figley (1).

Arbeidshelse er et begrep som kan relateres til både arbeidsglede, arbeidsmiljø og jobbstress. Stress i forbindelse med utfordringer på jobb kan være positivt og gi arbeidsglede, et godt arbeidsmiljø og god arbeidshelse. Negativt stress kan skyldes mangel på forutsigbarhet, slik det kan erfares om arbeidspresset blir større enn det vi kan håndtere.

Eksempler på dette kan være påkjenningene vi kan oppleve når for stort tidspress hindrer nødvendig konsentrasjon, når vi opplever manglende kontroll over eget arbeid, eller når hensynet til helse, miljø og sikkerhet settes til side (2).

\section{Følelser påvirker helsen}

Å leve seg inn i og forsøke å forstå andre menneskers følelser, slik sykepleiere må gjøre i møte med pasienter og brukere, innebærer at vi lar oss berøre. Vi bruker våre sensitive evner til å fornemme noe av hjelpsøkerens livsverden, slik at han eller hun kjenner seg sett som menneske. Denne evnen kan øke både treffsikkerheten og fagligheten i møte med den som søker helsehjelp (3), samtidig som den samme evnen kan gi arbeidsglede.

\section{三 «Innlevelsen kan koste oss dyrt når vi berøres for sterkt.»}


Innlevelsen kan koste oss dyrt når vi berøres for sterkt og ikke får hjelp til å bearbeide dette. Vi kan da stå i fare for å utvikle en tretthet, også betegnet som compassion fatigue, og sakte, kanskje nesten umerkelig, utsettes for en utbrenningsprosess (4).

Empatien kan slik sett være både vårt største aktivum i arbeid med pasienter og en stor utfordring for oss som hjelpere. Begge deler, å åpne opp for å la seg berøre og det å berøres for mye, kan altså påvirke arbeidshelsen vår.

\section{Systemverden og livsverden}

Faktorer som påvirker arbeidshelsen vår, kan beskrives med instrumentelle begrep som eksponering og risiko for skade når arbeidstakere belastes av systemrelaterte arbeidsmiljøfaktorer. Vi kan også omtale slike arbeidsmiljøfaktorer som en systemverden som består av organisering av arbeid, budsjetter og eksteriør, og som noe som kan komme til å stå i motsetning til vår livsverdens moralske og relasjonelle aspekter. Systemverden kan også inneha kvalitetsbeskrivelser som formidler normer for hva som er god og forskningsbasert praksis.

Noen ganger gir ikke systemverden tilstrekkelig tid til å utføre god og forskningsbasert praksis. Når sykepleiere, som andre profesjonsutøvere, utsettes for denne motsetningen, beskriver de det ofte som å være i skvis og i en moralsk utfordrende arbeidssituasjon. Systemverden kan da, ved sine ordninger og beskrivelser, noen ganger påføre både pasienter og sykepleiere smerte.

Relasjonsarbeid er knyttet til livsverden og den enkelte sykepleiers personlige kompetanse. Relasjonsarbeid er (5) sammensatt og kan beskrives som en finslipt komposisjon av sensibilitet, berørthet, erfaringsbasert kunnskap, retningslinjer og evidensbasert teori (3, s. 222-23). 


\section{Fellesskap gir styrke}

Veiledning kan bidra til kompetanseutvikling og et fellesskap som kan være en motstandsressurs i krevende arbeidssituasjoner (6). En annen virkning av veiledning i grupper, som også kan beskrives som en motstandsressurs, er det kollegiale fellesskapet som kan oppstå mellom for eksempel sykepleiere i en veiledningsgruppe (7). Vi har hørt sykepleiere som arbeider med for eksempel selvmordsforebygging eller med traumatiserte, si at de aldri ville greid å være i dette arbeidet uten veiledningsgruppens fellesskap.

Vi har også erfart at systematisk sykepleiefaglig veiledning i grupper gjennom arbeidsåret kan bidra til lavt sykefravær, og til at færre i sykepleierstaben skifter jobb.

Vi skal også være oppmerksomme på at enkelte ikke opplever at veiledning er nyttig. Dette kan skyldes mange ting, som for eksempel manglende struktur i gruppen, veilederen eller selve gruppeprosessen blant deltakerne.

\section{Kan forebygge utbrenthet}

Veiledning og oppmerksomt nærvær om det som skjer i praksis og med oss selv, kan både forebygge utbrenthet og bedre pasientomsorgen (8).

I veiledning er dialoger om opplevelser, forståelsesformer, kunnskap, handlingsvalg og løsningsforslag knyttet til praksiserfaringer samt deling av etiske og faglige refleksjoner, den viktigste arbeidsformen (6). Deling av erfaring på denne måten kan gi en kumulativ virkning (9), slik at hver enkelt veisøker kan ha med seg mer kunnskap når de går ut fra en veiledning enn de hadde da de kom til veiledningen. Dette kan både beskrives som en del av et fagfellesskap og en del av en felles kompetanse- og kvalitetsutvikling. Dette fellesskapet kan bidra til samlet fagforståelse og kompetanseutvikling i en sykepleiestab. 


\section{$\equiv$ «Samtaler om faglige utfordringer i veiledningsgrupper kan motvirke ensomhet, motløshet og usikkerhet.»}

Dersom veiledningen skjer i tverrprofesjonelle eller tverrfaglige fora (10), kan virkningen av veiledning innen helse- og sosialsektoren bidra til økt forståelse og fellesskap mellom profesjoner og fagfelt.

Når sykepleieren står med ansvar for liv og helse og for å gi en helhetlig omsorg, kan det oppleves ensomt. Samtaler om faglige utfordringer $\mathrm{i}$

veiledningsgrupper kan motvirke ensomhet, motløshet og usikkerhet.

«Sammen er vi sterke» kan være en betegnelse for opplevelser knyttet til gruppeveiledning. Dette kan ha betydning for kontinuitet og arbeidsglede, som igjen kan ha betydning for lysten til å lære og til å utvikle kvalitet og kompetanse i sykepleiepraksisen.

\section{三 «Fellesskapet kan bidra til tydelige og stolte sykepleiere.»}

Veiledningsfellesskap kan styrke arbeidsmiljøet og føre til bedre trivsel. Når sykepleiere reflektere sammen over utfordringer i jobben, kan det bidra til at alle får mer kunnskap, og til at kvaliteten på arbeidet de utfører, blir bedre. Dette kommer pasientomsorgen til gode. Fellesskap i veiledningsgrupper kan gi faglig styrke. Styrken kan knyttes til mot. Fellesskapet kan bidra til tydelige og stolte sykepleiere.

\section{Referanser}

1. Figley CR. Compassion fatigue as secondary traumatic stress disorder: an overview. I: Figley CR, red. Compassion fatigue: secondary traumatic stress disorders from treating the traumatized. New York: Brunner/Maze; 1995. s. 1-20. 
2. Arbeidstilsynet. Stress [internett].Oslo:

Arbeidstilsynet; 4 juli 2014 [sitert 12.02.2019].

Tilgengelig fra:

https://www.arbeidstilsynet.no/tema/stress/

3. Nordtvedt P, Grimen H. Sensibilitet og refleksjon. Oslo: Gyldendal Akadmisk; 2004.

4. Bang S. Rørt, rammet og rystet. Faglig vekst gjennom veiledning. Oslo: Gyldendal akademisk; 2003

5. Skau GM. Personlig kompetanse. I: Ulvestad KA, Kärki FU, red. Flerstemt veiledning. Oslo: Gyldendal Akademisk; 2012.

6. Vråle GB. Veiledning når det røyner på.... Oslo: Gyldendal Akademisk; 2015.

7. Vråle GB, Borge L, Nedberg K. Etisk refleksjon og bevisstgjøring i veiledning [internett]. Oslo: Sykepleien forskning 25.04.17 [oppdatert 24.05.17, sitert 11.07.18]. Tilgjengelig fra: https://sykepleien.no/forskning/2017/04/etiskrefleksjon-i-veiledning DOI:10.4220/Sykepleienf.2017.61626

8. Hoffart Rake AR, Larsen SH, Rø K. Hjelper mot utbrenthet. Veiledningskurs om stress og utbrenthet førte til bedre pasientbehandling. Sykepleien.

2014;102(2):46-8

9. Nordbøe CE, Enmarker I. The benefits of personcentered clinical supervision in municipal health care employees` experiences. Open Journal of Nursing. 2017;7(5):548-60.

10. Just E, Nordentoft HM. Tværfaglig praksis. København: Hans Reitzels Forlag; 2012. 